\title{
VIRTUAL HERITAGE FOR THE DISSEMINATION OF THE BARATTI IN 3D PROJECT
}

\author{
G. Nicastro ${ }^{1}$, P. Puma ${ }^{1, *}$, \\ Deptartment of Architecture, University of Florence, 50121 Florence, Italy - (giuseppe.nicastro, paola.puma)@unifi.it
}

KEY WORDS: virtual archaeology, archaeological survey, digital representation, Populonia’s monumental necropolis

\begin{abstract}
The paper describes the final step of the Baratti in 3D project, aimed at the dissemination of the important archaeological heritage of the Etruscan city of Populonia (Tuscany, Italy). The chain of "data metrical surveying - 2D and 3D representation communication" has been applied on the "Princes's tombs" of the monumental necropolis of San Cerbone and its finds to provide a detailed description of their context, workmanship, morphological characteristics and materials to realize the virtual recreation. The preservation of the finds from the excavations in two different museums far from the archaeological area (the Museo Archeologico Nazionale di Firenze and the Museo Archeologico del Territorio di Populonia, in Piombino) makes the understanding of the original context very difficult for visitors. Thus the "Baratti in 3D Project" has been conceived in order to document the tombs, their finds and produce the "virtual match" showing in its entirety the environmental and architectural provenance and material ritual context and in order to display in innovative visual approach this archaeological heritage. To complement the interactive platform, as a physical fallout of this project has been realized "A museum in every sense”, a permanent exhibition in the Museo Archeologico del Territorio di Populonia.
\end{abstract}

\section{INTRODUCTION}

\subsection{Framework of the research}

The end of "restoration archaeology" and the loss of an highly imaginative dimension of the reconstructive representation at the end of the nineteenth century represents a turning point in the relation between architects and archaeology, as well as a change of the architects' role, who begin to give up with the downright archaeological research, but keep a necessary presence alongside archaeologists.

The opportunity -not always consciously and critically fulfilled- to stay in the balance between objective description and subjective interpretation of artifacts has long provoked that the relation between architects and archaeology be dual and dialectic; nowadays it has accomplished a greater clarity of scientific approach, conceptual methodology, and material instrumentation in the various disciplines characterizing the present cultural education of the architect.

The current potentialities of virtual archaeology allow the general public, archaeologists and museum curators to well understand the contexts and somehow retrieve, with modern technologies and languages, the "restoration of archaeology" and the highly imaginative aspect of the reconstructive representation interrupted at the end of the 19th century.

The scientific research in the field of surveying and digital representation of archaeology has well established methodologies that have seen an ever-increasing hybridization with new languages: a more advanced use of 3D visualizations to describe the environment has forced us to look more closely at those experiences of digital visual storytelling and multimedia languages, i.e. movies and videogames.

Therefore, the virtual reconstructions based on the data collected during the surveying campaigns offers the possibility to make interactive simulations and thematic interpretations of an archaeological context and to display complex information in visual way using a communication tuned on a wide and diversified audience of users.

Finally, this kind of promotion of archaeology in all categories of citizens, together with the renewal of approaches and languages, is the crucial key to attaining cognitive and emotional knowledge through active educational activities.

In this framework, has been conceived the Baratti in 3D Project, aimed at apply the best practices of virtual archaeology on the relevant heritage of the Etruscan city of Populonia's monumental necropolis, Tuscany, Italy.

Most of the burial buildings have been measured, processed and represented in traditional 2D drawings and in 3D models (Puma, 2014) as well as finds from two tombs but, since all the finds are exhibited far from the necropolis (in the Museo Archeologico del Territorio di Populonia, in Piombino, and in the Museo Archeologico Nazionale di Firenze), it is very difficult for the visitor to imagine this context in its original unitarity of natural environment, architectural settlement and place of funerary rite.

To facilitate the understanding of the context and the provenance of the finds the Baratti in 3D project has been conceived to produce the complete documentation of the necropolis of San Cerbone and of numerous finds excavated from its "Tombs of the princes" to proceed with the virtual recreation (Fig. 1)

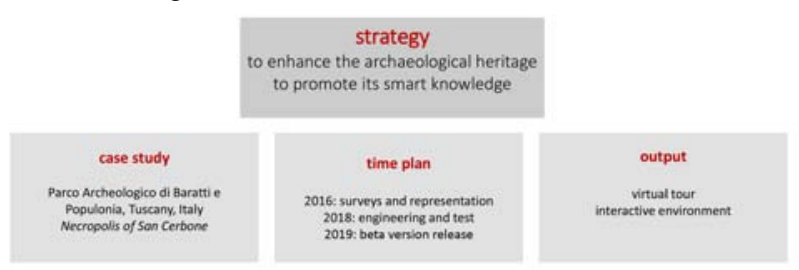

Figure 1. Baratti in 3D Project: project chart

\footnotetext{
${ }^{1}$ Although the paper was conceived jointly, Paola Puma is the author of the paragraphs 1, 2.2, 2.3, 2.4, 2.6, 3, Giuseppe Nicastro 2.1, 2.5, and the figures.
} 


\section{DEVELOPMENT OF THE RESEARCH}

\subsection{Subject of the research}

Populonia was for centuries a major iron production centre, favoured by its proximity to the sea - being the only Etruscan city with this peculiarity - and by its position in front of the Tuscan archipelago, at the junction of important Mediterranean trade routes.

The necropolis surveyed is situated in the area called San Cerbone-Casone-Porcareccia, and it stretches at the sea-level inland the Gulf of Baratti, although it was part of the original settlement lying on the ridge. It was discovered quite recently, mostly due to the finding of artifacts during the digging out of iron slag in the first half of the twentieth century.

The first official excavations were started in 1908, and they brought to light an Etruscan sepulchre near the Letti Funebri tumulus, as well as a Villanovan necropolis.

But during the four decades from 1916 to 1957, several companies carried out a massive state licensed operation to extract the iron that had covered, hidden and protected the ancient necropolis.

The use of digging machinery entailed the devastation of artifacts, but also the disclosure of the original landscape and features of the area that had been concealed by a thick blanket of debris up to ten meters deep and more.

In the two decades following the closure of the pit, research activity became sporadic, while in 1960 the necropolis of San Cerbone was acquired by the Italian State and opened to the public in 1998. Much of the promontory where the city was settled in antiquity is today the area of the great and important Parco Archeologico di Baratti e Populonia, ample about 80 hectares, where it is possible to visit various necropolis of the Etruscan age and the Acropolis of the Roman Pupluna.

The most important necropolis of the park is the Monumental Necropolis of San Cerbone, consisting of a large number of burial structures, still being excavated, ranging from the seventh century B.C. to the third century B.C., and are mainly concentrated on three main types (burial mounds, oikoi, sarcophagi). As mentioned before, the relevant finds from the excavations are currently kept in two museums far from the archaeological area (Fig. 2).

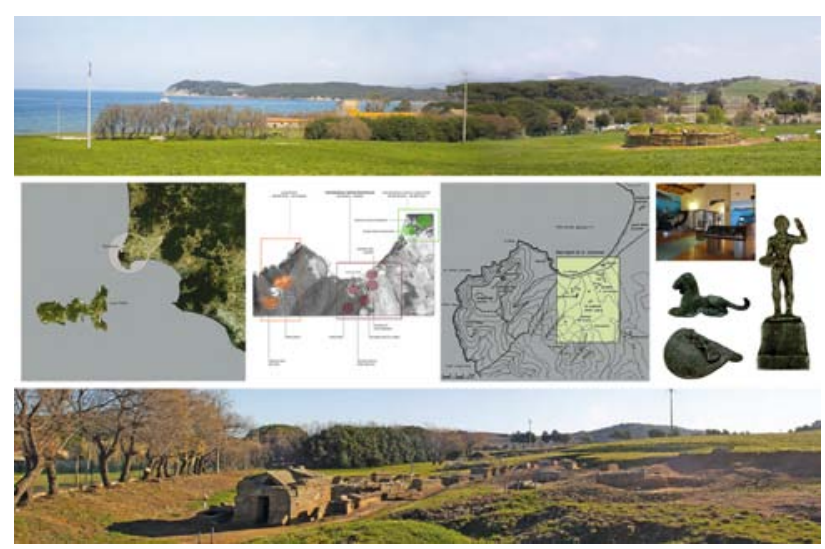

Figure 2. The context of the project: the Populonia's monumental San Cerbone necropolis

\subsection{Methodology of the research}

The work presented in this paper refers to the theoretical, methodological, and instrumental field of the architecture's Survey and Representation.
The methodology of the study was constituted by the chain of "data metrical surveying - 2D and 3D representation communication” organized into three steps (Fig. 3):

1.DATA METRICAL SURVEYING

- acquisition of morphometric data of the Etruscan tombs, realized by integrated survey (laser scanner, topographical survey, SFM);

- acquisition of morphometric data of the archaeological finds from two tombs, realized by SFM;

2D AND 3D REPRESENTATION

- 2D drawings;

- digital 3D models of the tombs and of the finds; COMMUNICATION

- "virtual recreation" in order to show in its entirety the environmental and architectural provenance and material ritual context.

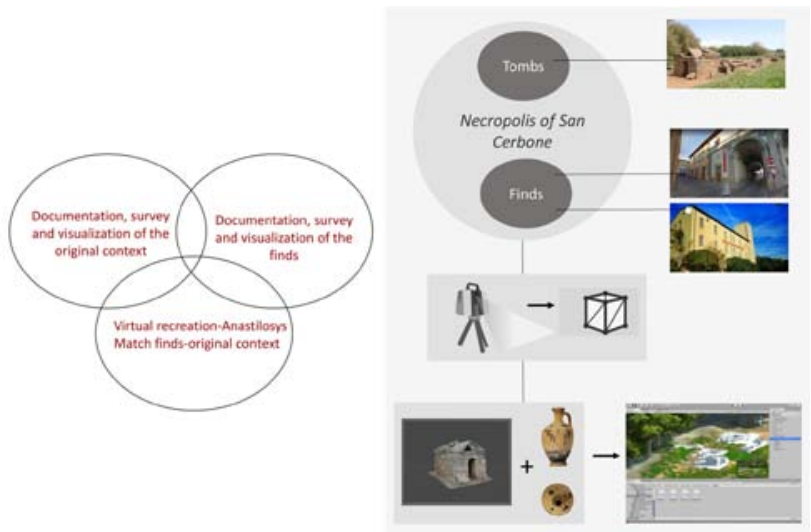

Figure 3. Concept of the project

\subsection{Data metrical surveying}

The step 1 of the program has been carried out with an integrated approach according to the characteristics of each object the various methodologies and instrumentations applicable to "direct" or "indirect" surveys: topographic, laser scan, traditional, "fast" photogrammetry (using single ortophoto elevations and photomodeling).

In order to optimize the understanding of architectural features that enable to situate the artifacts both in space and, though approximately, in time, one needs to carefully document not only the metric-dimensional data but also those related to the architectural quality of all the buildings.

In the period 2007-2014 about 25 tombs of the necropolis have been indagated and the architecture's survey has been conducted in seven workshops.

As usual in the architecture's survey for archaeology, all documentation needs were ensured by the integration of detection methods that involves a multi-resolution approach aimed at capturing data characterized by a variable resolution: for the classification of the evidence in the local territorial context, topographic survey and laser scanning were used (for the representation of the plans and environmental sections), while for the detailed survey a case-by-case calibration of the set of applicable methodologies and instruments for indirect or direct survey was used: "traditional" survey, mono camera photogrammetry for 2D and 3D representation (fast photogrammetric and photomodeling).

In 2015 the first survey campaign of the grave goods from two graves (Tomba del Bronzetto di Offerente and Fossa della 
Biga) took place at the Museo archeologico del Territorio di Populonia, in Piombino.

The documentation work carried out for the first finds had a duration of 5 months, divided into three phases: the preliminary screening and planning working together the museum's staff, the acquisition of data and survey campaigns (we were authorized to keep the finds outside the alarmequipped glass boxes only for a short time; which means we had to use various shooting sets simultaneously), the representation of data. By calibrating 3 different settings of data acquisition (with photo-frames in different angle/circle overlapping and different positions of the object on the target board) and through processing, we reached the quality objectives defined by metrically reliable $3 \mathrm{D}$ reconstructions in double graphics output: geometric "not real" output for the appreciation of the dimensions and morphology of the pieces and texturized output for the visual appreciation of their workmanship value and characteristics of the material.

The survey results were rated as excellent by the archaeologists, with respect to the project's time and budget limits, in up to $80 \%$ of of the 54 finds documented.

\section{$2.42 \mathrm{D}$ and $3 \mathrm{D}$ representation}

The step 2 of the program has been conceived in three phases: - $2 D$ drawings of the tombs: the drawings are all produced in thematic double series, dimensioned drawings and morphological drawings, in a scale of $1: 20$ or $1: 50$; the standard series of descriptive graphs has been produced of each artifact: plans, elevations and sections, with the related photomosaics.

The graphs are characterized in a qualitative sense with a "naturalistic" rendering with particular regard to the conservation characteristics of the burials, in order to obtain graphs that are also descriptive of the construction quality and of the degradation conditions in which the tombs are today.

For reasons related to the computer archiving of data (with the possibility, therefore, of continuous access to the database of dimensional data from CAD drawings), it was considered essential to accompany the morphological representation with the dimensioned one, in order to have access to the numeric dimensional data in immediate coherence with the visual features of morphological-material type.

- 3D models of the tombs and of the finds: the need to have visualizations of the detected artifacts in 3D for future dissemination has suggested orienting the choice of language towards digital models of numerical type (realized with integration of software for modeling and the subsequent rendering processing); 3D models have been thus realized in graphical output of two types: in computer graphics "not-real" to represent the cases in which it was useful to check some critical junctions of the 2D or photorealistic drawings in cases when oriented towards simulation for dissemination purposes, as in the case of the burial mounds.

Given the large amount of data acquired during the Laser Scanner survey, before starting the $3 \mathrm{D}$ processing, it was necessary to break down the pointcloud into parts referring to the single tombs detected, (while still maintaining a reference system); proceeding in this way the load in terms of hardware resources has been reduced, making the data to be processed easier.

Before meshing the surfaces it was necessary to perform some filtering actions of the acquired points: through the application of pertinent algorithms, special sw allow to reduce the "noise" generated by unwanted measurements and to lower the density of the points (where excessive redundancy is present) thus speeding up the subsequent meshing phases.

During the surface processing, attention was paid to all aspects related to the optimization of 3D models: if a high-density polygon model always guarantees a detailed geometry at all scales, for low-density models (i.e. consisting of a smaller number of polygons and a resulting lower level of detail) ensure instead a better use of hardware resources when used in real-time digital environments as in Baratti in 3D. The mesh procedure has been then completed by eliminating from the models all the unwanted surface portions: by applying a smoothing filter all the roughness caused by the residual noise were eliminated thus ensuring the uniformity of the generated surfaces (Fig. 4, 5, 6).

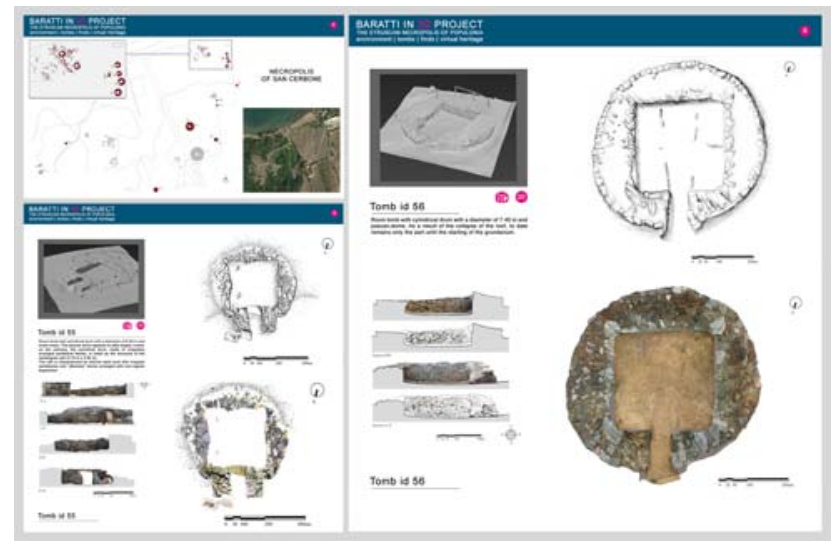

Figure 4. The tombs survey in the platform's repository

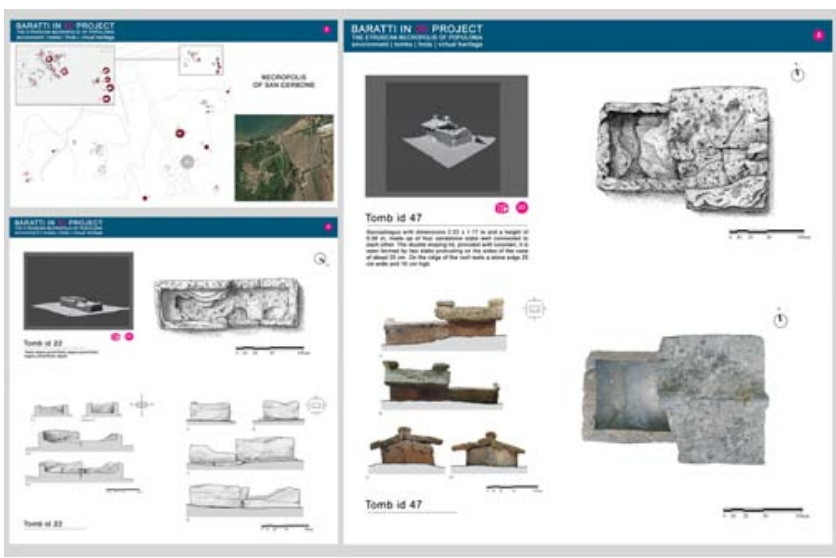

Figure 5. The tombs survey in the platform's repository

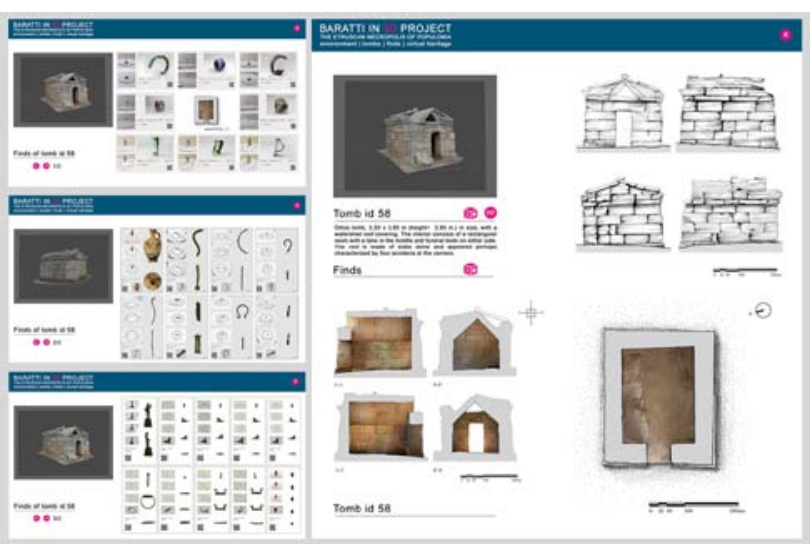

Figure 6 . The tombs and finds survey in the platform's repository 
Finally, by integrating the data acquired from the LS survey with the clouds generated with SFM (having all the information related to the color of the detected objects), the photorealistic textures to be applied to the 3D models were produced (Lachambre et al., 2017).

- the data collection to constitute the repository storing the 3D models: the data from the surveying campaigns were collected and appropriately catalogued in a digital repository designed to be consulted through web-based mode and stand-alone mode. Browsing an interactive map which represents the area of intervention it is possible to access different types of contents like 2D drawings, pictures, texts and 3D models. The features of the digital repository allow a visual cataloging of the acquired data (3D charts, 3D models, texts, photos, etc) easily to be integrated into websites and portals: the platform is based on the html5 standard and its web oriented nature guarantees the possibility to host the entire repository on most web server today available and to be used on different devices.

\subsection{Communication}

The role of virtual archaeology in Baratti in 3D project has been conceived following the consecutive main principles and guidelines on virtual heritage established since 2008 (Icomos (2008), 2009 (London Charter for computer-based visualization of cultural heritage), 2011 (Principles of Seville, International principles of Virtual Archaeology), 2013 (Charter on the Preservation of Digital Heritage) and focusing on the conceptual procedures and practical operations that the Seville Charter puts between Anastilosys ("Virtual anastylosis: this involves restructuring existing but dismembered parts in a virtual model";) and Virtual recreation ("Virtual recreation: this involves using a virtual model to visually recover an archaeological site at a given moment in the past, including material culture (movable and immovable heritage), environment, landscape, customs, and general cultural significance.”).

The step 3 of the program has been realized by the design of the digital platform displaying the archaeological site in interactive way. To realize the interactive environment we have opted for the use of Unity3D sw, one of the most used real time rendering engine in both professional and consumer environments. Real-time engines is a sector born mainly in contexts closer to the entertainment sectors (Video Game, App., 3D Animations, etc.) and finds wide and wide diffusion even today in scientific divulgation (Bekele et al., 2018).

The possibility of creating highly programmable 3D environments, with a suitably credible environmental physics and lighting management, and finally the possibility to develop and bring their projects on different platforms (PCs, Smartphones, information totems, low and high cost $\mathrm{Vr}$ systems), make these applications extremely versatile and efficient; this wide versatility, however, corresponds to an adequate level of know-how in skills sometimes extremely different (from programming languages such as Java or C \# for scripting phases, to 2D and 3D graphics for management of the models, etc.).

Another aspect of the project was therefore the realization of work assets that facilitated the most complex programming phases: using precompiled code portions (released under UnityEula license) the scripts related to the management of the interactive environment control system have been realized (Microsoft Development Team, 2018).
The First Person Controller script, that is the portion of code that deals specifically with the management of the camera (simulating the user's point of view), for example, has been optimized to ensure the use of the platform through the combined use of mice and keyboard (devices more suitable for desktop use) (Unity Development Team, 2018).

In contrast, the First Person Controller Touch script was used to ensure the best experience when using the platform through touch devices such as smartphones and tablets.

Finally, we envisage an additional variable of these scripts and the use of pre-compiled Gvr assets (Google Development Team, 2018), to make the interactive platform usable by standalone $\mathrm{Vr}$ devices.

The management of the events and interactions with the elements present in the 3D scenario has been entrusted to an Event Triggerig script: all the 3D models are equipped with a Mesh Collider, i.e. a sensitive area that interacts with the camera to which one is coupled RayCasting script that allows you to activate predefined actions (Fig. 7).

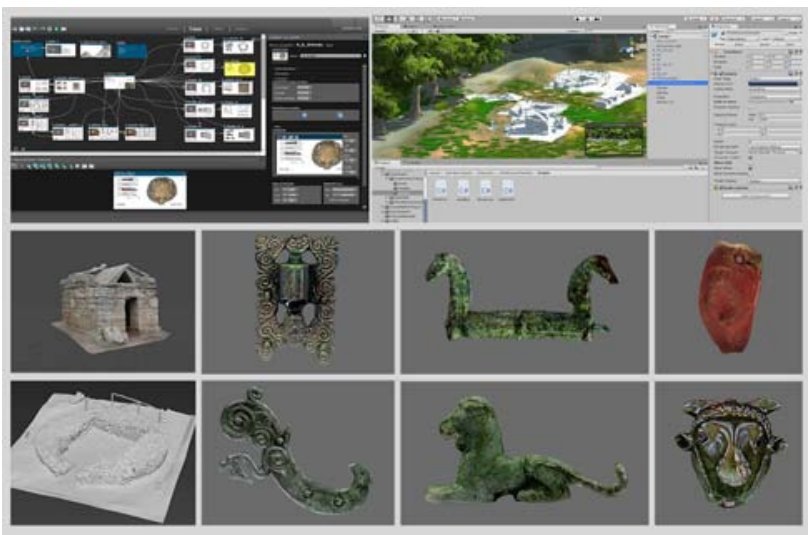

Figure 7. Phases from the interactive platform processing

\subsection{Results}

The platform offers an interactive environment designed using real time rendering technologies both on the site and online. Unlike static rendering engines, dynamic rendering engines allow us to create freely explorable 3D environments equipped with dynamic lighting systems, realtime simulation of physical effects and the possibility of adapting the user control systems to different types of devices (laptops, smartphone, tablet, etc.) (Fig. 8, 9).

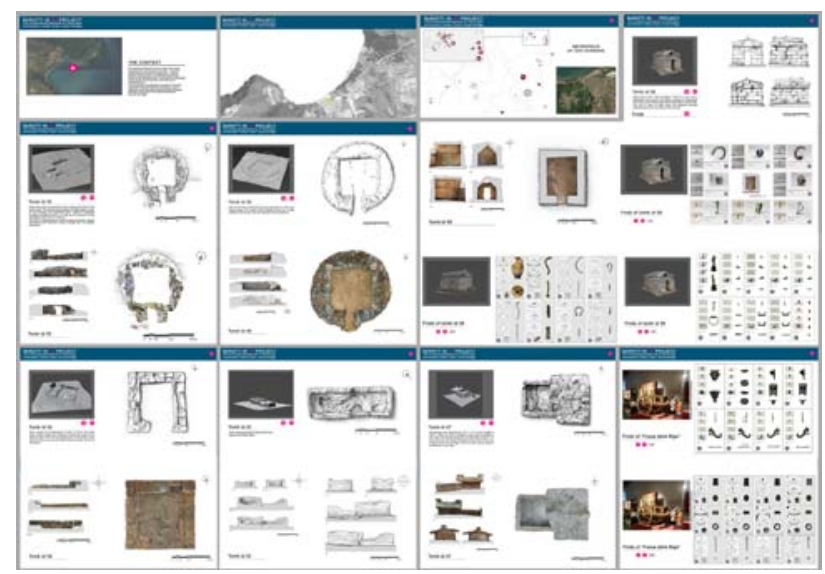

Figure 8. Home of the digital interactive platform 


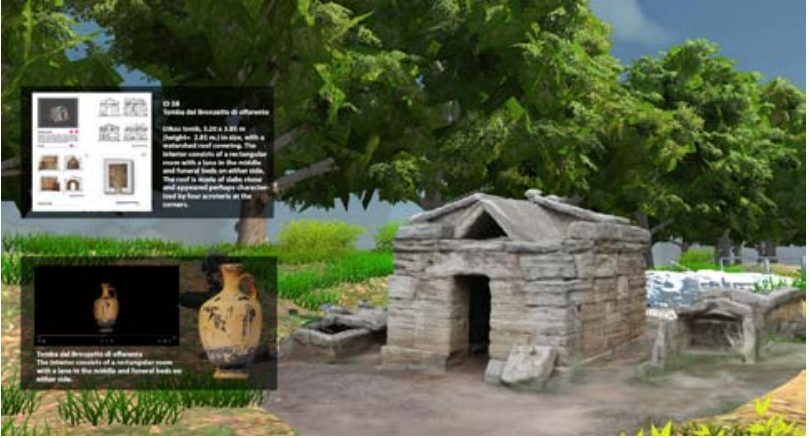

Figure 9. Frame from the digital interactive environment

In addition to the digital platform, as a physical fallout of this research has been realized the project "A museum in every sense”, a permanent exhibition in the Museo Archeologico del Territorio di Populonia.

Framed within the general aims "Open new doors for the application of digital methods and techniques in archaeological research, conservation and dissemination" (Principles of Seville, International principles of Virtual Archaeology, 2011) in this project we have applied electronic engineering to three replicas of the finds making it interactive, realizing an innovative approach to the knowledge of archaeology and allowing a subsequent rapid expansion of the museum's audience.

The research project "A museum in the every sense" was born with the aim to test an innovative strategy of cultural communication using technologically advanced ways of fruition of archaeological finds mixing storytelling and coding.

Letting the objects in the museum "talk" to the visitor and creating an interactive environment it is possible to establish a true dialogue with the visitor-user, generating stimulus and the foundation of an effective cultural process.

The project focused on three well known artifacts belonging to the Museo Archeologico del Territorio di Populonia, in Piombino; two of them are archaeological artifacts located in the necropolis of San Cerbone in the Parco Archeologico di Baratti e Populonia (the Etruscan Tomb of the Chariots and the Roman marine mosaic) and the third is the most important find in the museum: the Anfora di Baratti.

The Tomb of the Chariots is the largest tomb in the monumental necropolis and the best known and most significant example of the "tombs of the princes" that make the monumental Necropolis of San Cerbone so important in the Etruscan funerary archaeology (Zifferero, 2000).

The marine mosaic was made entirely of marble, between 150 and $100 \mathrm{BC}$, and takes its name from the seabed that is represented, populated by 25 marine animals.

The Anfora di Baratti is a valuable vase dated around $400 \mathrm{~d}$. C., and it is supposed to be wrecked on a ship coming from Antioch or Rome. The feature that makes it an item so rare is being completely covered by 132 ovals, finished by chisel, arranged in 10 lines; the amphora is made of $96 \%$ pure silver inferring the exceptional aesthetic level of such a precious object.

The three archaeological artifacts were documented in three surveys campaigns (the data acquisition process was calibrated in three different procedures: LS for the Tomb of the Chariots, fast photogrammetry for the marine mosaic, LS in Hyper quality for the Amphora of Baratti) and the three objects were then reproduced in 3D printed prototypes.

The final step of the preparation stage was to embed the prototypes with touch sensors which thus become "talking objects": through the engineering of models, in fact, an interactive museum context is created, where the visitor interrogates the object that explains itself in visual and sounding way (Fig. 10).
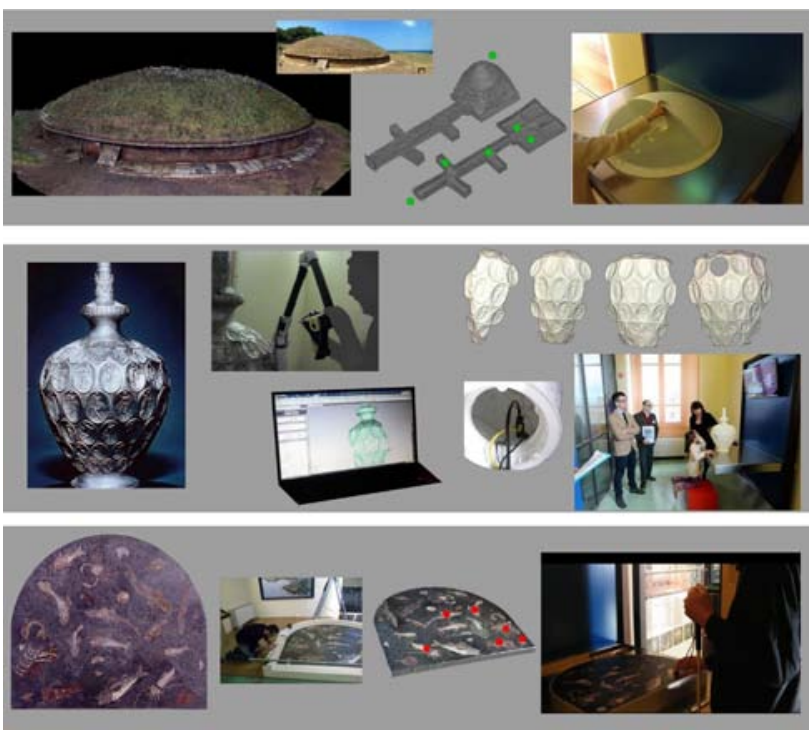

Figure 10. Un Museo in tutti i sensi project

\section{CONCLUSIONS}

The monumental necropolis of San Cerbone consists of approximately 200 remains, of which we have investigated the 30 most important tombs and two sets of their grave goods (about 50 finds). Both the remains and the finds have been measured, described in their morphology, size, geometry, material nature and represented in 2D drawings and metrically reliable 3D models; finally, the "match" allowed us to virtually "reproduce" their provenance context. For example, looking at one of the graves in the scenario, you can see the original find from the burial again in the original position they were found during the excavation, as well as a series of graphic/textual contents screen, which enrich the browsing experience and favors the understanding of the artifact that is being observed. Most of the procedures and tools we used in the project are well known, not original and we have adopted it as they have appeared as innovations during the development of the project. The innovation of Baratti's in 3D project consists therefore in the conception of a longtime program that has produced the first complete documentation ever acquired of this archaeological context in its environmental, architectural and finds components, reuniting them according to the original situation and technologically fully-evolved.

The possibility of operating a virtual match between burials and finds that lie far apart between them increases the degree of intelligibility of the museum areas, favoring the understanding and involvement of users through tools and technologies that are now daily used.

\section{ACKNOWLEDGEMENTS}

The "Baratti in 3D Project" has been supported by Soprintendenza Archeologia della Toscana and Parchi Val di Cornia spa. "Un museo in tutti i sensi" was supported by scientific partners (Soprintendenza Archeologia della Toscana), 
funding institutions (Regione Toscana), partner institutions (Comune di Piombino, Parchi Val di Cornia spa).

\section{REFERENCES}

Bekele, M. K., Pierdicca, R., Frontoni, E., Malinverni, E. S., and Gain, J., 2018. A Survey of Augmented, Virtual, and Mixed Reality for Cultural Heritage. In: Journal on Computing and Cultural Heritage (JOCCH) Vol. 11-2, pp. 7:36.

Bertocci S., \& Arrighetti, A., 2015, Survey and documentation for archaeology. a special issue of Scires-it 5(2). http://caspurciberpublishing.it/index.php/scires-it (01 December 2018).

Brusaporci, S., (ed.), 2015. Handbook of research on emerging digital tools for architectural surveying, modeling, and representation. Igi Global, Hershey, pp. 1-829.

Digital Heritage, 2015. Proceedings of the meeting Granada 28/09 - 2/10/2015, Curran Associates, Inc., New York, pp. 1 286 ,

https://ieeexplore.ieee.org/xpl/mostRecentIssue.jsp?reload=true \&punumber $=7406203$

Google Development Team, 2018. Documentation for app developers, Google LLC https://developer.android.com/docs/ (02 November 2018).

Icomos, 2008. The charter for the interpretation and presentation of cultural heritage sites. http://www.icomos.org/charters/interpretation_e.pdf (01 December 2018).

Ioannides M., Fink E., Brumana R., Patias P., Doulamis A., Martins J., Wallace M., 2018. Digital Heritage Progress in Cultural Heritage: Documentation, Preservation, and Protection, Proceedings, Part I \& II of 7th International Conference, EuroMed 2018, Nicosia, Cyprus, Springer International Publishing, Heidelberg, Vol. 1, pp. 1517, Vol. 2, pp. 1-310.

Ippoliti, E., Meschini, A., 2011. Tecnologie per la comunicazione culturale. Disegnarecon,4(8).

https://disegnarecon.unibo.it/issue/view/276/showToc (01 December 2018).

Lachambre S., Lagarde S., Jover C., 2017, Unity. Photogrammetry Workflow. UnityTechnologies. https://unity3d.com/files/solutions/photogrammetry/UnityPhotogrammetry-Workflow_2017-07_v2.pdf (02 November 2018)

London Charter for computer-based visualization of cultural heritage. 2009. http://www.londoncharter.org/fileadmin/templates/main/docs/l ondon_charter_2_1_en.pdf (01 December 2018)

Microsoft Development Team, 2018. Visual Studio Documentation, Microsoft Corporation https://docs.microsoft.com/enus/visualstudio/?view=vs-2017 (02 November 2018).
Pescarin, S., 2016. Digital Heritage into Practice. SCIRES-IT, 6(1). http://caspurciberpublishing.

it/index.php/sciresit/issue/view/772 (01 December 2018).

Principles of Seville, International principle of Virtual Archaeology, 2011. http://smartheritage.com/wpcontent/uploads/2015/03/FINAL-DRAFT.pdf (01 December 2018)

Puma, P., 2014. Contributi per il rilievo archeologico di Populonia. La necropoli monumentale. Edifir, Firenze, pp. 1299.

Puma, P., 2016. The Digital Cultural Heritage-DigitCH programme: experiences of documentation and survey for the smart fruition of archaeological heritage. In: Scires SCIentific RESearch and Information Technology, Vol. 6/2, pp. 151-164, DOI 10.2423/i22394303v6n2p151

Puma, P., 2017. From survey to 3D: the representation of the archaeological heritage in the project "A museum in every sense". In Territories and frontiers of the representation, proceedings of $39^{\circ}$ convegno internazionale dei Docenti della Rappresentazione, Gangemi, Roma, pp. 1113-1120.

Puma, P., 2018, Multidisciplinary experiences of virtual heritage for the documentation of architecture and archaeology within the DigitCH Group - Digital Cultural Heritage Group, in Ioannides M., et al., 2018. Digital Heritage Progress in Cultural Heritage: Documentation, Preservation, and Protection Proceedings, Part I \& II of 7th International Conference, EuroMed 2018, Nicosia, Cyprus, Springer International Publishing, Heidelberg, Vol. 1, pp. 1517, Vol. 2, pp. 1-310.

Remondino, F., Campana, S., 2014. 3D Recording and Modeling in Archaeology and Cultural Heritage. Theory and best practices, BAR International Series 2598. Archaeopress, Oxford, pp. 1-171.

Romualdi, A., 1983. Guida archeologica di Populonia. Vision, Roma, pp1-48.

Unity Development Team, 2018. Unity User Manual (2018.2), UnityTechnologies https://docs.unity3d.com/Manual/index.html (02 November 2018).

Zifferero, A.. 2000, (ed.), L'architettura funeraria a Populonia tra IX e VI secolo a.C. All'insegna del Giglio, Firenze, pp. 1268. 